\title{
Lake Nakuru Black Rhinoceros Sanctuary
}

\section{Christopher Lever}

In an attempt to stem the decline of the black rhinoceros Diceros bicornis in Kenya, the Rhino Rescue Charitable Appeal Trust was formed in England in 1985. Within a year work on the first sanctuary, in the Lake Nakuru National Park, had begun. The sanctuary was opened in 1987, when 17 rhinos from Mr Courtland Parfet's private ranch at Solio joined the two animals already in Nakuru. A further 11 females are due to be added to the park shortly. Rhino Rescue, of which the author is a patron and trustee, is also developing its own education programme, and is contributing to other rhino sanctuaries in Kenya.

The decline of the black rhinoceros Diceros bicornis in Africa is well documented (Western and Vigne, 1985). It is now mainly confined to isolated pockets in the east and south-east of the continent and in Namibia. In Kenya the black rhinoceros population has fallen from $18,000-20,000$ in 1970 to 511 in 1987, a decline of over 97 per cent. In the last 7 years the population has dropped from 1500, a decrease of 66 per cent (IUCN, 1988). In addition to poaching, another reason for the decline of the black rhino is the rapid growth in the human population. At around 4 per cent per annum Kenya, for example, has one of the highest growth rates in the world. With increasing reclamation of land for farming and demand for wood as fuel and building material, the rhino's distribution has shrunk dramatically.

In an attempt to stem this disastrous decline, the Rhino Rescue Charitable Appeal Trust was formed in England in December 1985, under the presidency of HRH Prince Bernhard of The Netherlands. The aim of the Trust is to help the government of Kenya achieve the objective of its rhino conservation strategy plan to build fenced sanctuaries for the beleaguered animals.

In March 1986 an appeal was launched in the House of Lords in London; this proved so successful that within a year sufficient funds had been raised to begin construction of the first sanctuary. The site chosen was the Lake Nakuru National Park in the central Rift Valley, $140 \mathrm{~km}$ north-west of Nairobi.

Lake Nakuru (Figure 1) is a shallow alkaline soda lake $71 \mathrm{sq} \mathrm{km}$ in extent, bordered on the west by a steep and rugged wall of the Rift Valley, with volcanic cliffs rising to $2743 \mathrm{~m}$, and on the east by a salt-dome hill. The lake is encircled by swamps, and the surrounding land supports an arid transitional savannah, with the lake's marginal grasslands of salt

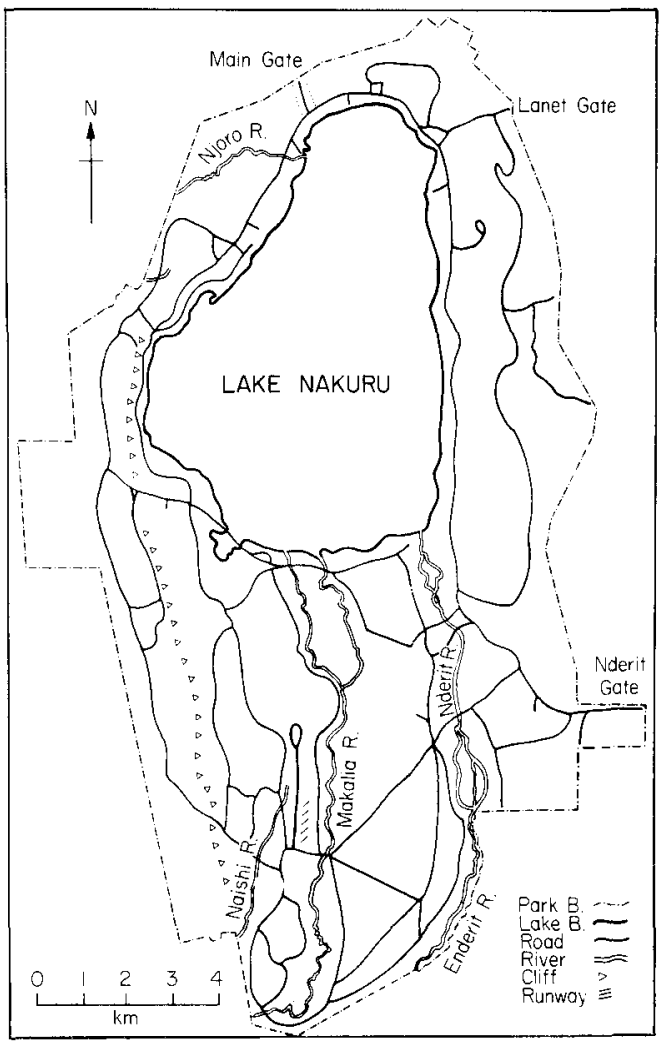

Figure 1. Map showing Lake Nakuru National Park. 
grass Sporobolus spicatus and sedge Cyperus laevigatus giving way to grasslands of Hyparrhenia hirta and in the lower areas Rhodes grass Chloris gayana. On the higher ground are found: xerophyte forests of Acacia xanthophloea, olive Olea hochstetteri, and Croton dichogamus; Euphorbia candelabrum forest; and bush country dominated by the composites, mulelechwa Tarchonanthus camphoratus and Psiadia arabica (IUCN, 1987). All this is prime rhino habitat.

With financial contributions from private individuals and other conservation organizations, generous donations of materials and services from elsewhere, and $£ 300,000$ provided by the Trust itself, work was begun on enclosing the 200-sq-km park surrounding the lake and the lake itself. A 74-km-long, 3-m-high, 12-stranded electrified fence was built, consisting of 11,038 wooden posts, many driven into stony ground, and $888 \mathrm{~km}$ of high-tensile steel wire strung through 33,114 electrical insulators. Every $15 \mathrm{~km}$ there is a manned guard post equipped with automatic anti-tamper alarms, solar panels to provide electrical power, and radio communications. Every alternate wire on the fence is electrified; the 700 non-lethal volts they provide have proved enough to deter intruders and to keep rhinos within the sanctuary, but are not sufficient to prevent olive baboons Papio anubis, who have learned how to avoid the electrified wires, from climbing over the fence.

Bulldozers have been used to create a firebreak along the fence outside the sanctuary and a maintenance road on the inside. Within the sanctuary a further $60 \mathrm{~km}$ of patrol tracks and bridges have been driven through the bush to provide access for mobile patrols. Each patrol has been equipped with a radio for communication with the Trust's headquarters, comprising the administrator's house, stores, maintenance facilities, a radio room and an office. Nearby are the holding pens, where the rhinos are acclimatized on their arrival at Nakuru before being released into the wild, and a release ramp.

Three rivers feed Lake Nakuru, which has no outlet, but they run only for some three months a year, thus making the water development aspect of the project of great importance. With financial assistance from other

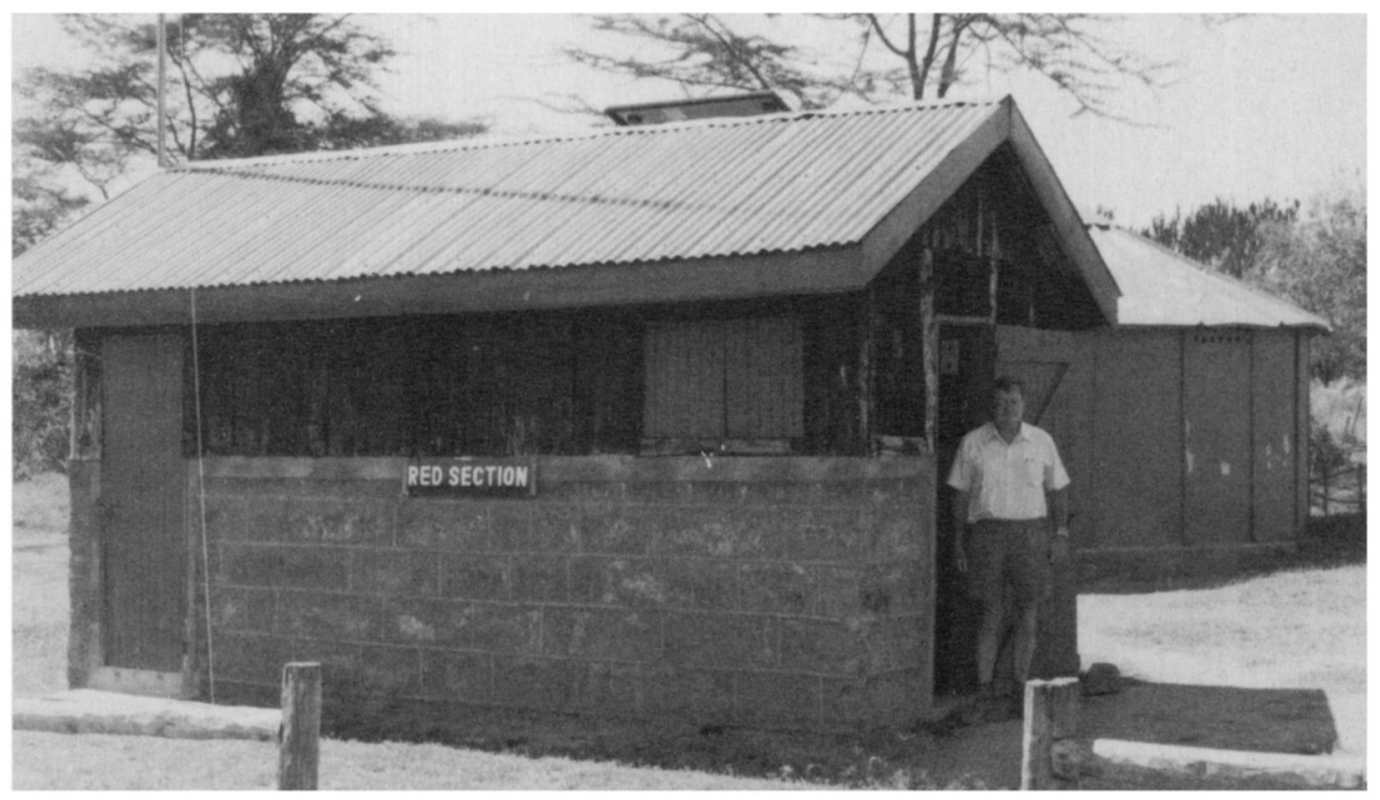

Guard post. 
conservation groups, natural waterholes in the sanctuary have been enlarged, deep boreholes sunk and piped water laid on to drinking troughs. Rhino Rescue has also helped to finance the construction of two 12-million-gallon dams, using machinery supplied by the Kenyan Government under the supervision of the West German Water Development Agency. Surveys of the park's volcanic soil, which is interspersed with alkaloid deposits, have revealed deficiencies in copper and cobalt; this has been remedied by the introduction of appropriate licks.

On a visit to Nakuru in March 1989 I was able to see the Trust operating at first hand. The value of the firebreak outside the perimeter fence was shown to good effect when it, and the combined fire-fighting ability of the Trust's personnel and the park's staff, alone prevented the spread into the sanctuary of a dangerous bush fire from the neighbouring estate of Lord Delamere. Camping in the park at the time was a party of young people of several nationalities from Operation Raleigh, and a detachment from the band of the Grenadier Guards, both of whom, under the direction of a corporal from the Royal Engineers, were rendering sterling service to the Trust by helping to construct a bridge over a deep ravine.

Conservation alone, however, is not enough. To ensure the ultimate success of any project, people, and especially children, must be taught to appreciate the value and importance to them of wildlife and natural habitats. To this end, Rhino Rescue is developing its own education programme. This began with talks to school children visiting Nakuru; these proved so popular that a four-wheel-drive vehicle fitted with a television screen will shortly be acquired, which will enable the Trust to visit local schools and show films about African wildlife. Later a generator will be purchased, thus allowing the unit to travel further afield and give film shows to outlying schools.

The Trust has undertaken to fund the major part of the running costs of the sanctuary (estimated to total around $£ 75,000$ per annum) for an initial period of 3 years. It has installed its own administrator to protect and administer its investment, and to liaise with the park authorities.

Rhino Rescue has also undertaken to fund a

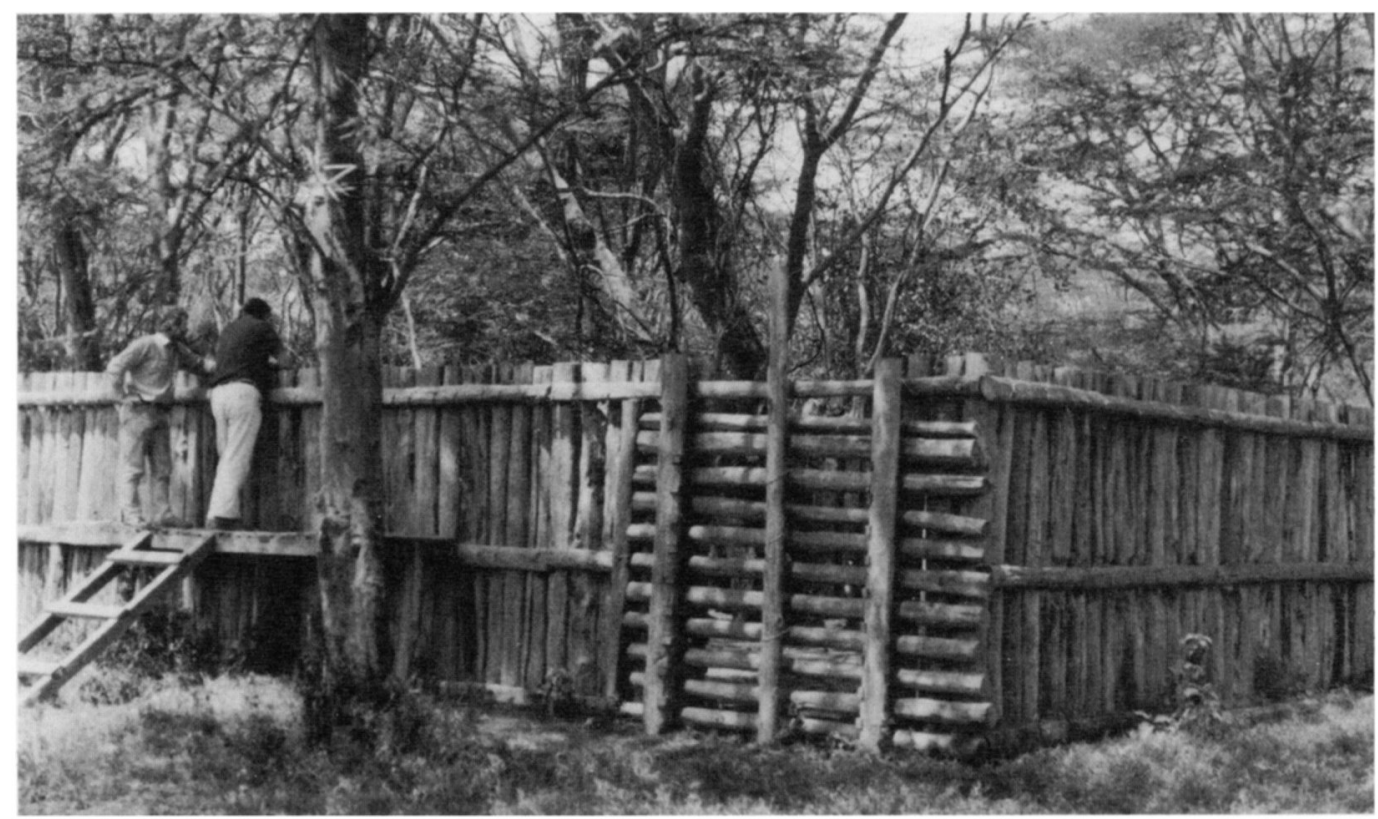

Holding pen. 


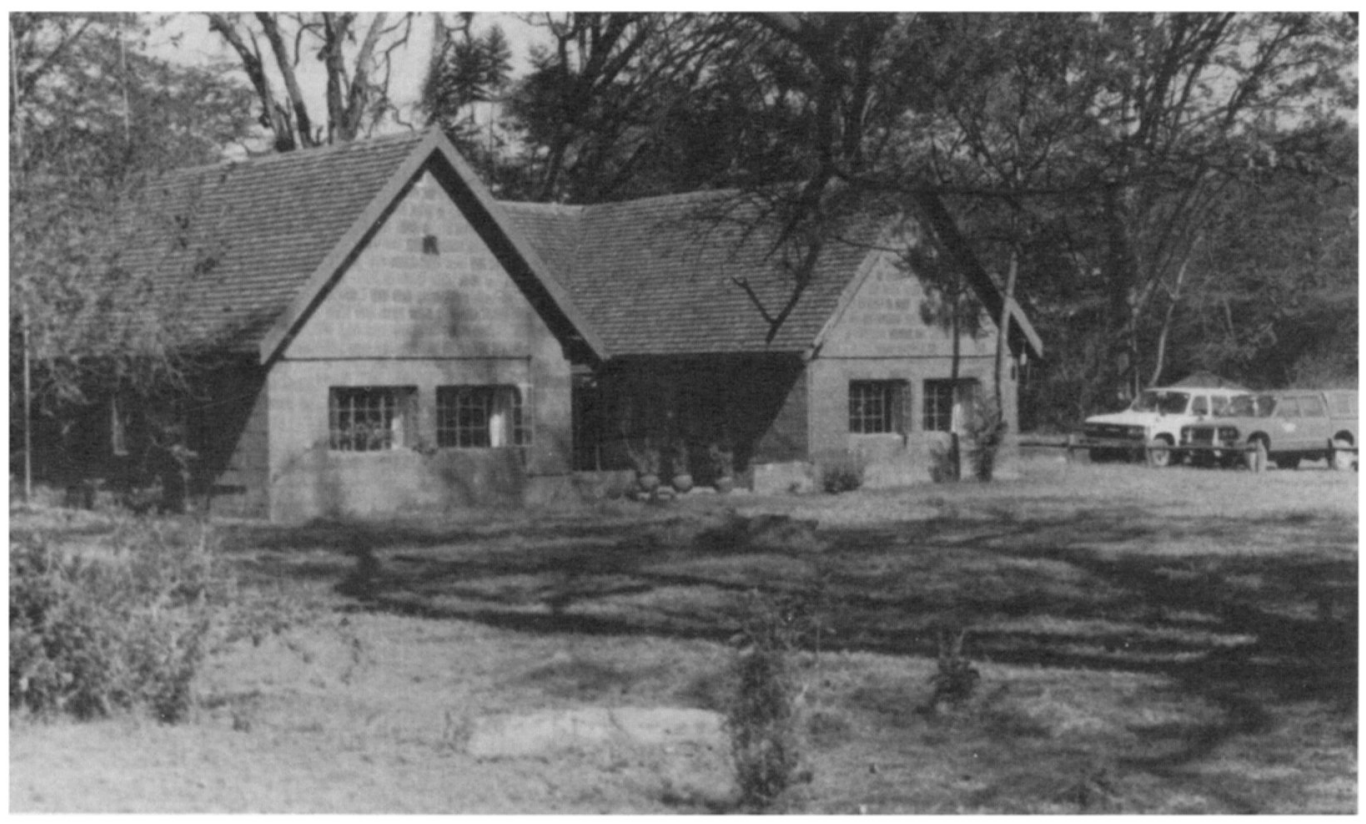

Administration building.

further increase in the size of the rhino sanctuary started by the Zoo Check Charitable Trust in 1985 at Ngulia near Mtito Andei in the Tsavo West National Park, $190 \mathrm{~km}$ south-east of Nairobi, where the erection of a further $20 \mathrm{~km}$ of fencing will increase the total area of this sanctuary to some $60 \mathrm{sq} \mathrm{km}$. Shortly after the first three female rhinos, caught near Kibwezi and Taveta, were freed in Tsavo, a male broke in through the perimeter fence, and has remained there ever since. Recently another male, who had killed two white rhinos Ceratotherium simum at $\mathrm{Ol} \mathrm{Jogi,} \mathrm{and} \mathrm{had} \mathrm{subse-}$ quently been de-horned, was translocated to Ngulia, where he in turn was killed by one of the resident rhinos. This unfortunate occurrence adds cogency to the many arguments against the de-horning of rhinos, certainly in Kenya, as a solution to the problem confronting conservationists. Since 1985 two rhino calves have been born at Ngulia, where the total number of rhinos in the sanctuary is now 10, and where a similar number from Solio (see below) is due to be added shortly.

Thanks to a generous donation from the David Shepherd Conservation Foundation,
Rhino Rescue has also contributed to the construction of a further sanctuary in the Salient of the Aberdare National Park, a little over 100 $\mathrm{km}$ due north of Nairobi.

No account of the campaign to save the black rhino would be complete without mentioning the contributions of such individuals as Dr Esmond Bradley Martin, an American geographer and one of the patrons of Rhino Rescue, who is working to abolish the illegal trade in rhino (and elephant) products, and the efforts of Mr Michael Werikhe to raise funds for the rhino by his sponsored long-distance walks through Europe and East Africa.

Only 18 months after the launch of the Rhino Rescue Appeal, the first black rhinos were released in Nakuru, to join the two already within the National Park. Seventeen animals were transferred from the private Solio ranch near Nyeri, (which in addition to supporting a population of no fewer than 85 black rhinos also contains a group of 30 introduced white rhinos) owned by an American, Mr Courtland E. Parfet, another patron of the Trust. The founding stock was deliberately kept low to encourage the animals to breed more freely. 


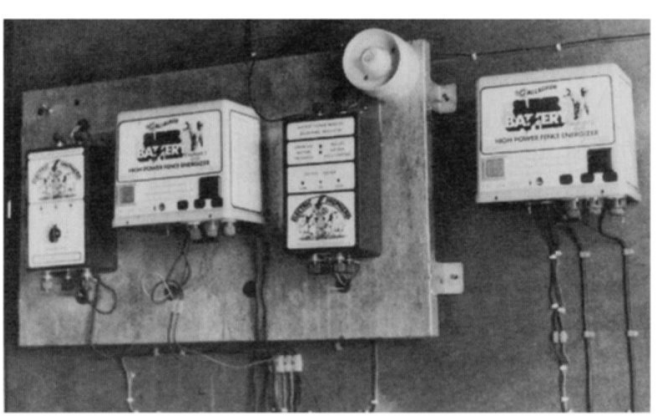

Automatic anti-tamper alarm system at guard post.

Without the foresight of Mr Parfet in creating his private sanctuary at Solio, the work of the Trust would not have been possible.

Records are maintained on each animal at Nakuru, and its social behaviour and interaction with other rhinos are carefully monitored; this is important to prevent stress, which could lead to fighting. Black rhinos are not gregarious creatures and problems can arise if populations become too great for a given area. Even when the population is not large, difficulties can arise. Shortly after the rhinos were transferred from Solio to Nakuru, an immature female was attacked and injured by an adult female. After treatment of her wounds in the holding pens she was released, only to be attacked and injured again. On the second occasion she rather touchingly returned to the holding pens for treatment of her own accord, and after recovery was transferred from Nakuru to a private sanctuary. If and when the population at Nakuru becomes too great, surplus animals will also be transferred to other public or private sanctuaries.

When a rhino is shot with a tranquillizing dart, placed in a holding pen and allowed to become settled in its surroundings, it normally becomes accustomed to people looking after it within 3 or 4 days, and after a week can be transported by vehicle to its new home.

The policy of the Kenyan Government of constructing fenced and well patrolled rhino sanctuaries within its national parks is to be commended. If the new sanctuaries on public land prove as successful as those on private ranches, they will have gone a long way towards halting the demise of the black rhino in Kenya.

A further 11 female black rhinos from Solio are due to be added to Nakuru shortly, which is now home to 19 animals (11 males, seven females and one calf born since the sanctuary was formed), and several of the females are believed to be in calf. From this breeding nucleus at Nakuru, which it is estimated can hold at least 60 adult rhinos, the future of the species in Kenya, where in 1988 for the first time in many years more rhinos were born than were killed, now seems assured. In time it is hoped that some animals can safely be returned to the wild in other unfenced national parks. This is Rhino Rescue's ultimate objective. That such a magnificent creature should ever be allowed to disappear from the earth is surely unthinkable.

In the second phase of its Appeal, Rhino Rescue is aiming to raise a capital fund of $£ 750,000$, the income from which would enable the Trust to fund the Nakuru sanctuary's annual running costs indefinitely. Donations can be sent to: Rhino Rescue, P. O. Box 1, Saxmundham, Suffolk IP17 3JT, UK.

\section{Acknowledgments}

I should like to thank Count and Countess Coreth for their hospitality at Nakuru and Count Coreth, the founder of Rhino Rescue, for his comments on my MS. My thanks are also due to Mrs Daphne Sheldrick for her personal communication.

\section{References}

IUCN. 1988. African Elephant and Rhino Specialist Group Report, 1988

IUCN. 1987. Directory of Afrotropical Protected Areas, pp 258-259, IUCN Gland.

Western, D. and Vigne, L. 1985. The deteriorating status of African rhinos. Oryx, 19, 215-22.

Sir Christopher Lever, Newell House, Winkfield, Windsor, Berkshire SL4 4SE, UK. 